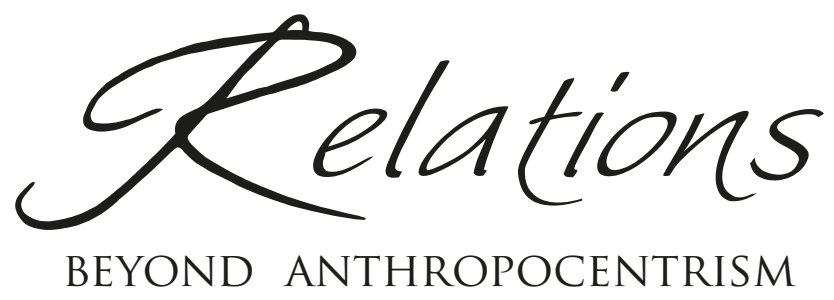

\author{
$9.1-2$ \\ NOVEMBER 2021 \\ Animals: Freedom, Justice, Welfare, \\ Moral Status, and Conflict Cases \\ Edited by Francesco Allegri
}

\author{
STUDIES \\ AND RESEARCH CONTRIBUTIONS
}

Pigs vs. Boars: The Ethics of Assisting Domesticated and Wild Animals

Beka Jalagania

The Chincoteague Ponies and What It Means To Be Free

Alexis Flower

Beyond the Fairy Tale of The Shape of Water: Reimagining the Creature

Viktorija Lankauskaite

Max Scheler e la possibilità di una nuova forma di antispecismo

Enrico R.A. Calogero Giannetto

Distributive Justice and Animal Welfare

Paola Morreale

Unitarianism or Hierarchical Approach for Moral Status?

A Very Subtle Difference

Francesco Allegri 


\section{Comments, Debates, Reports AND INTERVIEWS}

Animals and Justice: The Unfinished Journey

Paola Fossati

Author Guidelines 


\title{
Beyond the Fairy Tale of The Shape of Water \\ Reimagining the Creature
}

\section{Viktorija Lankauskaitè}

Kaunas University of Technology (Lithuania)

DOI: https://dx.doi.org/10.7358/rela-2021-0102-lank

viktorija.lankauskaite@ktu.lt

\begin{abstract}
Guillermo del Toro's "Shape of Water" (2017) has gained praise both from critics and audiences for its themes and storyline. In particular, a lot of creative and thematic weight is carried by the creature in the film - the Amphibian Man. As a character, it fits into the recent trend of morally positive and emotionally impactful monster representations, belping, among other things, to address the themes of acceptance and embracing of otherness. The aim of this paper is to explore the construction and portrayal of the Amphibian Man, and to take a closer look at the director's approach towards reimagination of the creature in today's landscape of cinema. The paper delves into del Toro's work to define him as auteur, reflects on the traditions and changes in creature cinema, and examines the portrayal of the creature in terms of language, sound, and image.
\end{abstract}

Keywords: acceptance; creature cinema; Guillermo del Toro; image; language; monster films; otherness; Shape of Water; sound; zoomorphism.

\section{INTRODUCTION}

The latest picture from famed fantasy-horror director Guillermo del Toro is a beautifully crafted whimsical fairy tale reminiscent of old-fashioned monster-movies; a timeless classic from a filmmaker presenting the most earnest and poetic work of his career. The Shape of Water is a must-see piece of cinema that will engulf your senses and gently squeeze beauty, acceptance and love into your heart. (Wade 2018)

This review of The Shape of Water, published in The Film Magazine, broadly encompasses the reception that this story, about a mute woman 
falling in love with an amphibian water creature, received both from viewers and critics. While the fairy tale like story and its themes are certainly worthy of attention and consideration, this paper aims to explore the construction and the portrayal of the Amphibian Man in the film (a monster in a monster movie) and takes a closer look at the director's approach towards reimagination of the creature in today's landscape of cinema.

\section{Guillermo del Toro as Auteur}

The features and tendencies found in del Toro's body of work will be helpful in determining the qualities of the film analysed here and will provide a deeper understanding of the author's intentions and creative style.

Generally, and particularly after Truffaut's introduction of the concept in the Cabiers du Cinema, the term auteur is known and used to describe someone who not only directs, but also writes, and/or films, or edits the film, or maybe even acts in it, i.e., an author of the film that could be credited for more creative decisions (Staples 1966). However, in cinema discourse, the term is also used to describe a director who has developed a certain style and whose body of work could be distinguished from other directors. Bassil-Morozow (2010) identifies two main aspects of this: all or most of the control over the filmmaking process, and a "distinct voice" with recurring themes, style, characters, and actors (7-14). Wes Anderson, Quentin Tarantino, and Tim Burton, among others, could be named as examples of such creators, and Guillermo del Toro proves no exception, as he writes and directs his own films, and maintains his distinctive style across them.

His visionary style could possibly be described as surrealistic. Fantasy, horror, history, ghosts, and monsters are recurring elements in his films. As he draws inspiration from classical literature, mythology, Catholicism, and comic books, these elements are woven together to tell intense and visually appealing stories (Tierney et al. 2014, 2-4; Adji 2019). Adji (2019) also ties del Toro's obsession with the fantasy genre to the theme of embracing otherness, as positively portrayed monsters are present in most of his films, along with other characters that do not give in to standards in one way or another. In his book Cabinet of Curiosities: My Notebooks, Collections, and Other Obsessions (2013), del Toro reveals searching for ways to make Hellboy and his sidekick Abe Sapien

Relations - 9.1-2 - November 2021

https://www.ledonline.it/Relations/ - Online ISSN 2280-9643 - Print ISSN 2283-3196 
(from his 2004 feature Hellboy) more elegant, to highlight their human side. Though some technicality comes into this too, as he says he wanted to make Hellboy something Ron Perlman could play, i.e., to find the actor underneath the character (249-250). In the same book, he also gives credit to fantasy not as a way to escape, as other filmmakers or audiences tend to put it, but as a way to see, "Fantasy is a great way of deciphering reality", he says (del Toro and Zicree 2013, 24), and this message appears to carry through most of his work.

Another significant feature of del Toro's filmmaking is the amount of detail implicit in his work (Ward 2014). He draws inspiration from different sources and his films are often the result of rather unlikely encounters. Interviews and The Cabinet of Curiosities reveal many different elements and ideas used in his work. Literature, comic books, works of art, films, and other inspirations pave the way for his ideas and their translation to screen. Though the director claims that only fifty percent of it is intentional (88), the details and messages that he includes help to paint a coherent and vivid picture.

The vividness of the pictures that del Toro produces could also be attributed to the use of colour and visual effects. The latter are often a fusion of prosthetic makeup and some computer-generated imagery (CGI), as observed by Adji $(2019,53)$. Adji also stresses the use of special effects makeup and the prevalence of dark green colour, but in The Cabinet of Curiosities Guillermo del Toro offers a more elaborate explanation on the choices he makes regarding colour. The director reveals his preference for contrasting palettes both for the films and for the design of monsters. The contrast of blue or cyan and gold or amber are the main colours that he uses as a layer on deep shadows and blacks, and in the end of the colour grading process, other colours are added, as needed. Interestingly, he distinguishes red as a colour used with particular care in his films, even in Hellboy (del Toro and Zicree 2013, 80). The same idea seems to be evident in his later film Crimson Peak (2015) where crimson is saved for special scenes and characters. Hellboy could also be mentioned as one of the better examples regarding the use of contrasting colours, as the contrast between Hellboy's red and Abe Sapien's blue is one of the more visually striking. The balance of blue or cyan (or teal) and gold (or orange) can be often encountered as a popular colour grading choice among filmmakers. What began as a journey towards more colour in cinema by adding blue and orange tints to break the routine of black shadows and white light (Misek 2010, 139-140), now appears to be a standard stylistic choice for professional filmmakers, and a goal for aspiring ones, sometimes with questionable results. Del Toro's use of these

Relations - 9.1-2 - November 2021

https://www.ledonline.it/Relations/ - Online ISSN 2280-9643 - Print ISSN 2283-3196 
colours appears to be darker, and more thought out. In the same book he also expresses his fascination with a specific hue of green: "There's a hue of green, an almost fishlike quality in certain paintings that has had a huge influence on me. But I don't know if that's come through in the movies. I've tried", he says (del Toro and Zicree 2013, 80). And although written in 2013 it reads very much like a wish of being able to transfer such colours onto the screen, so much so that The Shape of Water might be the embodiment of this. While Adji's $(2019,51)$ mentioned greens can be seen in some of del Toro's films (e.g., Pan's Labyrinth), the colour palettes that the director chooses, appear to be slightly more nuanced.

As briefly mentioned, The Shape of Water contains many of these characteristics and inspirations. Set in Baltimore, in 1962, the film follows the story of Elisa, a young mute woman who works as a cleaner at a mysterious government facility where she encounters an "Amphibian Man" a fishlike creature that is held there against his will. Developing fond feelings for the creature, Elisa decides to save him and bring him home, where her friend and neighbour Giles, a homosexual graphic designer, helps her to take care of him. Guillermo del Toro's style is evident in the themes of fantasy, monsters, otherness, as well as in the technical aspects of the film - the use of colour and visual effects. The film won Academy Awards for best directing, best picture, best original score, and best achievement in production design (Internet Movie Database N.D.).

\section{THE CREATURE IN CINEMA}

A few words on the different tendencies to portray "creatures" in cinema should be presented here, in order to better frame del Toro's characterisation of the Amphibian Man.

To begin with, horror films can be mentioned, where the monsters depicted might represent the threats that society faces, a certain metaphor where killing the monster means overcoming the challenges in real life (Punday 2002; Bloom 2010, 7-8; Grant 2018, 1-2). Bloom (2010, 8) also stresses such an approach as being time dependent, i.e., older films were more often built with this premise, while their newer versions were kinder to the monster. Another way, and more relevant here, is when filmmakers start raising questions about who the actual monster is, addressing racism, bullying, and similar themes of discrimination, along with other different levels of human intolerance (Bernardi and Jacob 2019). Stymeist (2009) explores the oppositions present in monster films,

Relations - 9.1-2 - November 2021

https://www.ledonline.it/Relations/ - Online ISSN 2280-9643 - Print ISSN 2283-3196 
where a monster breaking cultural boundaries and being out of place, usually represents "various threats to the integrity of modern life". With this thought, he also underlines the idea that modern life and technology win against the monster too, thus making such films monstrous themselves, with their ideological messages of the superiority of technology (ibid., 404). Though the conclusion is more in the realm of monster vs. technology, the tendencies the author touches upon apply to most monster films - monster as other, partly human, partly other animal, somewhat intelligent, dangerous, powerful, etc. (403). The notion of monster and technology also allows us to be reminded about one particularly complex and multifaceted monster - Frankenstein's creature in Mary Shelley's Frankenstein (1818). Born from an experiment and abandoned by his creator, seeking friendship and acceptance, the creature represents the problems in society at the time of the novel as well as today, and shows us the monsters in ourselves. "The most frightening part of nineteenth-century novels comes from the discovery of our own similarities to the monster", writes Bloom $(2010,3)$. The creature's sympathetic portrayal in the novel and its adaptations could stand as an example and inspiration for constructing similarly complex characters and the messages they represent.

The qualities present in recent monster depictions - conflict, otherness - translate to physical appearance too, as the portrayal of such creatures (images in cinema, broad descriptions in literature) is often elaborate, specific, yet often highlights their "different" features and beastlike qualities, often inspired by other animals. Here we can mention the importance of our relationship with them too, as Salisbury ([1994] 2011) points out, monsters with non-human animal features show our attitude towards other animals (128). One of the more prevalent tendencies of human vs. other animal portrayal is where the non-human animal is represented as an enemy, a danger to humans, and as an "other" overall, and this has been explored in Lights, Camera, Bark (Martinelli 2014). From the bizarre ideas of monstrosity, freaks, and man-animal hybrids in the Middle Ages (see Salisbury [1994] 2011), to seemingly understandable and widely accepted ways of portraying monsters now. One such way is often referred to as zoomorphism - when human characters have some (or many) features of other animals, as opposed to anthropomorphism, where other animal characters, often in animated movies, have human features e.g., a mouse walking on hind legs, a talking horse, etc. (Martinelli 2014, 238, 242). Mermaids have fish tails, werewolves might be shown as humans with fur, big ears and fangs, and not only as a wolf, the Beast in Beauty and the Beast has fur, a wolf/bear head and body, and, of course, 
claws. Tarzan is portrayed as having learned to live like a different animal (walking on four limbs, actively sniffing the environment, growling, etc.), not knowing civilisation, thus different from humans, not fitting into society. Some Harry Potter villains are described as other animals toosnake nose and eyes for Voldemort, a toad for Dolores Umbridge, a rat for Peter Pettigrew, and so on. Such features often portray their assumed bad qualities, villainy, or monstrosity. Sometimes these characters go through a transformation - becoming human (like Beast in Beauty and the Beast), freeing themselves from a "worse" disposition, or dying. This is a very common way to portray the creature - transformation is necessary for the resolution of conflict. However, with monster films, resolution often means death. Stymeist $(2009,404)$ attributed that to the idea of modern life winning over the monster, where monster films aim to show the viewers that technology solves everything, i.e., saves us from monsters and helps to get rid of them.

The relationships between creatures and other characters are also important for their favourable portrayal. Since the monster in the story can reveal the social norms and cultural forces of the time, or rather what is wrong with them, empathising with monsters helps us to situate ourselves in that context as well (Weinstock 2012, 276-279). This can be emphasised by the characters that are attracted by the creatures and befriended by them, as they can be of similar fate to the ones usually marginalised in the society - outsiders, misfits, orphans, impaired persons, or someone generally not fitting in with the crowd: Frankenstein's creature befriends a blind man, and a little girl that is not afraid of him (Bloom 2010, 16, 27); Toothless in How to Train Your Dragon (2010) is found and saved by the boy who is considered to be weak just because he does not want to hunt dragons; the ghosts in Tim Burton's Beetlejuice (1988) can only be seen by a depressed teenager whose parents fail to understand her; Runt, the giant from The Big Friendly Giant (2016) becomes a friend of an orphan girl, and so on. One might not be aware of the tendency, but once it is noticed, it is difficult to miss - flawed characters choose to see others beyond their flaws as well. However, as friendly as these creatures might appear in such portrayals, more often than not their monstrous nature, danger, and fight for survival are touched upon too. Sometime within the friendship that might develop, the viewers are reminded of the true nature of the characters, whether it is a more direct performance of anger, rage, or maybe even violence, or just a depiction of the creatures' strength and wildness once they get scared and cannot be controlled, e.g., Frankenstein's creature accidentally killing those who befriend him, as covered by Bloom $(2010,27)$. 
In summary, the creatures are often portrayed as "others", enemies, a cause to be scared of, or as threats to society and to the existing order. In terms of visual appearance - monstrosity might often be connoted through the perceived features of other animals, as they appear to indicate otherness and the prevalence of instincts. The characters can be introduced as villains, antagonists, or as a danger in general, but their good side and a reason to like them can be presented too, especially in recent films speaking about themes of discrimination, raising deeper political and philosophical questions through these visuals, often through interaction with other characters of similar fate. However, a kind of transformation appears to be necessary too for the resolution of the story, searching for equal appearance, proposing homogeneity and a need for acceptance, or life without creatures.

\section{4. “The Shape of Water” AND ITS Amphibian MAN}

With the background set, a closer look can now be taken at the creature that Guillermo del Toro constructed in the Shape of Water. Inspirations, references, and similarities to other like spirited stories will be covered, followed by a detailed account of the Amphibian Man himself, as presented in the film.

The first and the most recurring title quoted as the inspiration for this film is the classic monster film The Creature from the Black Lagoon (1954). Guillermo del Toro is quoted as thinking about how great it would be if the characters (the woman from the group of scientists, and the beast, the Gill-man they find) would end up living together (Internet Movie Database N.D.). The Amphibian Man of The Shape of Water has many similarities to the Gill-man of The Creature from the Black Lagoon. Both are human like bodies with transformations that allow them to live underwater, i.e., zoomorphed. The Gill-man's head has more fishlike features, his body is covered in scales, and he appears to have a more scary, monstrous presence overall. His treatment in the film is as such - a group of scientists are exploring the Amazon jungle and they try to capture the beast for studying. Del Toro's take is different with the female character falling in love with the creature (the notions of a similar idea could be felt in Peter Jackson's King Kong, but that ends tragically). What separates del Toro's reimagining of the non-human as a love interest from other films is that the perceived beast does not die, is not killed, and does not have to become human to be acceptable to others and to live happily ever

Relations - 9.1-2 - November 2021

https://www.ledonline.it/Relations/ - Online ISSN 2280-9643 - Print ISSN 2283-3196 
after. The final stand-offs at the ends of both films are also similar, but as the Gill-man in 1954 is shot at and dives underwater to die alone, the Amphibian Man survives, kills his enemy, and is followed into the water by the woman who loves him. She transforms a little, to adjust to living under water but survives and stays with him.

A very similar creature can also be seen in another one of del Toro's films - Hellboy (2004). A character called Abe Sapien, a sidekick to Hellboy, also appears to be more like human with the features of a fish - blue, wet looking skin (similar to the creatures in James Cameron's Avatar), gills, and fins. Though Abe is able to speak and can spend some time outside water with some help, both him and the Amphibian Man of The Shape of Water count on boiled eggs as their main source of nutrition, have a strong masculine appearance, and curiously enough, are played by the same actor - Doug Jones. While the Gill-man is more similar to the Amphibian Man from the perspective of the story and concept, the character of Abe bears more similarities visually. Some might even think that with The Shape of Water the director created a new life for Abe Sapien.

The story itself can be traced back to different forms and variants. The Little Mermaid by Hans Christian Andersen might be the most obvious example, sometimes referred to as the Little Mermaid for adults, but the Ashgate Encyclopedia of Literary and Cinematic Monsters reveals more similar stories. These stories commonly feature humans falling in love with mermaids or mermen - either willingly, or having been lured by their voice, beauty, and magical powers - though male human and mermaid (female) appear to be a more common duo. They often balance between the beauty and fantasy of the mermaids and the sea world they live in, and their danger and fatality. Their endings also balance between the death of one or the other character or their transformation either mermaid becomes human, or human becomes mermaid/merman. To put these in broader terms, the conflict of human and sea creature relations is at the core of most of the stories. However, the one that bears the biggest similarity to The Shape of Water appears to be a short story by Jane Yolen, "The Lady and the Merman" (1977), where a seemingly unattractive young woman falls in love with a merman and finally follows him into the sea (Wood [2014] 2016, 412-413). Even though in that story the woman dies in the water, it bears more similarities to the film - a merman, a woman of no extraordinary beauty, and no pressure to transform - than many other depictions with similar premises. That said, the already discussed inspirations and ideas that del Toro uses to construct his work are a clear indication that no single story alone could be the basis for the film. 
As references are being considered it is worth mentioning the origins of the Amphibian Man that the film itself addresses. A reference is made to the creature being brought from the Amazon River in South America and he is mentioned as being a god in a certain culture (or to a certain tribe that used to bring him gifts). This allows us to draw a few more examples from the myths that follow similar creatures. Wood ([2014] 2016, 411) reveals the element of a deity and unimaginable beauty in the image of mermaids and mermen. Such figures are associated with success for fishermen and boats at sea and ask that the sea is treated with respect in general, thus they can be both benevolent and dangerous. The myths closer to the Amazon tell the story of Serek-A - a half woman half snake creature, a bridge between life and death and mother of an anaconda. Another one is the Boto, a creature capable of changing form between human and dolphin (ibid., 414). Appearance wise, though further away in the world, Philippine folklore mentions Kataw, a merfolk with the upper body of a human and a fish tail, fins, and gills (Ruis and Derasin 2019, 60), as well as Siyokoy, a different species of merman, who have human form with no fish tail, but instead brown or green scales, webbed limbs and gills, and are generally considered more dangerous and animalistic (Bane 2016, 923). There are of course many more similar ones, and this merely sheds light on the possible thematic and visual inspirations of depicting such creatures on screen. One thing that appears to bind most of the images together, is the conflict or balance of beauty, fantasy, divinity along with power, strength, fatality, and danger. Not all such creatures are considered to be of great physical beauty, they might have other attractive qualities, such as voice and singing, magical, healing abilities, etc., but none of them are exclusively kind and beautiful, or exclusively dangerous, violent, and fatal - these qualities are present together, e.g., Tingoi, who are kind and generous, but only at the right time and if approached in the right way (ibid., 1001). This is very clear in the portrayal of the Amphibian Man as well. Like the mythological beasts whose godliness and beauty are mixed with danger and strength, and like other portrayals of human vs. other animal, here the creature's strength and dangerous nature are also addressed, and a few episodes illustrate this. Just as the viewers are happy with the Amphibian Man successfully hidden in Elisa's apartment, and just as they begin to enjoy him being safe, not harmed, and thus friendlier and appearing less scary, he gives in to his instincts and attacks and eats one of the house cats and, scared by Giles, attacks him too. However, later the creature uses his magical powers and heals Giles' wounds and makes him a little younger. The director chooses to show that the creature is dangerous and should be 
approached with caution but reminds us of his fascinating abilities too. The same strength and danger are also seen at the end of the film, but in a slightly more awe-inspiring way, when the creature stands up after being shot by Strickland (Michael Shannon's character), the antagonist who held him captive. The contrast between that tortured and weakened animal, and the creature standing before him with the promise of inevitable death is dramatically and visually appealing - "You are a god" - are the final words of the antagonist. These elements help to understand that the Amphibian Man is similar to his mythological counterparts in themes and in the conflicts that he maintains, rather than in appearance or one single storyline.

Following thematic inspirations, the film could be more thoroughly reviewed from three different angles, or means of constructing audio visual texts: Language, Sound, and Image - an approach borrowed from the Means, Axes, and Properties (M.A.P.) model (Martinelli 2020). In his text, Martinelli defines the "means" in the following way:

Means [are] the "tools" of audiovisual communication, that is, images, sounds and language - what we hear/listen to and what we see/read. The category of sounds includes any type of music, the noises that are audible in the text and the so-called soundscape (the totality of sounds that are naturally or artificially produced in a given environment). The category of images includes anything that is visible, from characters to inanimate objects, from landscapes to abstract representations. The category of language is situated in the middle, as it has both an audible component (the words that are spoken) and the visible (the words that are written). In principle, thus, the audio-visual means can be represented as a Venn diagram. (Martinelli 2020, 97-98)

A closer look at these elements should help to reveal the approach to the portrayal of the creature in a more technical way.

\subsection{Language}

First of all, we might be inclined to start with introductions, and it might be telling that the merman does not have a name, in credits he is referred as the Amphibian Man, similarly to the Gill-man of The Creature from the Black Lagoon, though in the 1954 film, the actors (one for the creature on land, another for underwater) that played the creature were not even credited. While Gill-man is something that threatens people, like Godzilla, or the dinosaurs from Jurassic Park, that the protagonists only want to get rid of, the Amphibian Man, given the premise, is a charac- 
ter with a different purpose, one that the audience would like to get to know more, thus, having no name might influence his identity in the film. However, it appears that the story, the visual appearance, and the idea in general are far more important than the creature having an actual name. The choice might be explained by the origins of the creature too - as he is captive, caught somewhere in the jungle, not having a name is reasonable.

Even if the Amphibian Man had a name, he could not introduce himself, or at least tell his name, because he does not speak human language. This is where things begin to look more interesting. The main character Elisa is mute, thus she cannot communicate with humans the common way, instead she uses sign language (Elisa being "different" from other people in her workplace and society, further defines her as an outsider, a "misfit" character prone to befriending other "misfits", as often is the case in fictional films and their portrayal of creatures. Though her difference - the scars on the sides of her neck, where her voice box used to be, also play an important role later). This allows for those two characters human and creature - to lose the barrier of language, or rather speech, in general. If they are both not able to speak, they find other ways to communicate. The Amphibian Man learns sign language from Elisa, and they develop their own way to speak to each other. "What is beautiful for me is that every single character that has the power of speech has problems communicating, and the two characters that do not have the power of speech - they are mute or wordless - they are actually communicating beautifully”, says del Toro (Whitley-Berry 2017, \$ 7).

\subsection{Sound}

Music is another form of communication the main characters choose. Elisa loves cinema and music and transfers that love to the Amphibian Man by playing him vinyl records. The creature responds to music and responds to Elisa's dancing in his own way. After seeing them dance and listen to music together, the doctor in the lab (Mr. Hoffstetler) also starts to believe that the creature is more intelligent and is able to feel and communicate. Del Toro shows the importance of music in the screenplay too, where music or song for each scene is already decided and referred to (del Toro and Taylor 2016).

In terms of non-diegesis, Alexandre Desplat's score creates a fantastic atmosphere, drawing inspiration from the sounds of water, as well as from the way it feels, as he sees water at the centre of the film (Grobar

Relations - 9.1-2 - November 2021

https://www.ledonline.it/Relations/ - Online ISSN 2280-9643 - Print ISSN 2283-3196 
2017). The music rolls in waves and immerses the viewers in love and warmth. The creature's theme sounds more mystical, primal, and dangerous, but also with an element of fantasy, combining the thematic elements and contrasts of a sea creature, as discussed before.

The creature himself also has a distinctive sound. Initially, the sound is reminiscent of the sound of a dolphin but as some interviews reveal, the range of sounds used is much broader. Included were the voice of the sound editor Nathan Robitaille, sounds of swans, parrots, frogs, and other animals. Water is also an important element, as it is supposed to move through the gills, and generally is a source of life for the creature. Just as the voice of humans mostly consists of air travelling through the cavities in our head and body in various ways, the creature's voice needed to account for water travelling in the same way too. One of the unexpected sounds that tied it all together was the voice, and especially the breathing, of Guillermo del Toro himself. The example of this can be clearly heard in the scene with the creature just brought to Elisa's bath and gasping for air (Walden 2017).

The overview of sound reveals the brilliant teamwork that went in to making the film, how the details that each separate element bring, complements each other and helps in building the version of the creature we see on screen.

\subsection{Image}

Both from the perspective of the director and his voice as auteur, and from the film itself and its appealing quality overall, the image might be the most important aspect in the portrayal of the creature. This is where all of the references, inspirations and imagination meet. The colours and visual effects, the environment that the director chooses to put the character in, all helps to construct the image of the Amphibian Man, or as the director himself says, everything in the film serves the creature: "You have the outer core - cinematography, production design, wardrobe, colour palette and all of that. And right at the centre, is the monster. Everything else serves the monster. That's a monster movie" (Jenkins 2018, \$2).

As mentioned before, the Amphibian Man resembles a man, but has the qualities of an underwater creature: gills, fins, and webbed limbs. The skin appears to be cold and glistening, yet strong and resilient, as the creature itself is muscular, though his movements are more elegant in the water than on the ground. His eyes remind us more of those of a fish, while the lips are more similar to those of a human. Such a combination of 
zoomorphism allows us to glimpse at an actor underneath as well (underneath practical visual effects - costume and make up, not CGI), just as del Toro wishes. His screenplay describes the creature as "Beautiful, Majestic, Pure", while other unwelcoming characters use the words like "ugly", "untamed", "animal", "dangerous" (del Toro and Taylor 2016).

The care for colours and colour symbology is particularly remarkable. The shades of green and blue can be seen in almost every scene and in many things - walls, clothes, cars, key lime pie, and everything in between. "That's the future now. Green", says Bernie, an advertising agent that Giles tries to sell his work to. While the shades of green were used with the intention to create the unsettling mood, a more bluish shade, or teal, represents the future (James 2017). Alternative shades within the film are warmer - browns, mustards - used for the friendlier characters such as Giles, Zelda, Dr Hoffstetler (Grobar 2018, $\$ \$ 14-15$ ). Sometimes red appears on screen too, mainly in Elisa's wardrobe, more so as her relationship with the creature develops (and the contrast of blue and red reminds us of the contrasts between Hellboy and Abe Sapien too). However, in this film too, del Toro's use of red is careful and calculated. The shades of green, teal, and blue also, without much hesitation, point to water as well, as it is an important element of the film. Even though it can be regarded as environment, it is vital to the character we are studying. It is his life and his home. The viewers also learn that water has a special meaning to Elisa too, as she was an orphan found in the water, so it might be easier to understand that the sea becomes home to both of them at the end. The presence of water, both on screen and as an idea also allows for the use of colours that Guillermo del Toro has been so fascinated about, as well as to give the film that overall iridescent visual atmosphere. These colours translate to the creature too. The shades of teal, blue, black and tan are present on his skin, as well as some more impressive effects - bioluminescent markings (as described in the screenplay), that light up and change colours when the creature is excited or uses his magical powers. The production design can also be mentioned with its idea to show the monster as a god, even when he is held captive in the lab. The pool there was constructed to appear like a ziggurat temple with the figure of a rising sun above, made of the round tank and pipes (Zahed 2018, $\$ 7$ ).

When it comes to cinematography, camera angles provide a more specific starting point in the discussion. The creature is often viewed from below, which accentuates his strength, size, and power. The shots are often wide, which might hint at showing the creature's relationship with others - when he is being tortured, when he is with Elisa, and so 
on - rather than the creature alone. Though the close ups, to show the beauty of the monster, are not too rare. The camera movements are smooth, continuous, and "floating", as they too aimed to simulate the movement of water. This idea and a tight budget brought some challenges (Chimera Lighting N.D.), but the vision of the director and the work that was put in by the production team was translated beautifully and the final result shows that. The approach towards visuals and camera work is also a nod to practical filmmaking, where most of the film's look is achieved in-camera, and very little is left for post-production. Such an approach might also depend on the budget, but it definitely shows the mastery of the filmmaker, the level of the knowledge of their craft, and the attention to detail instead of relying solely on technology - even if these possibilities are endless.

Overall, the visuals give the film the quality of a fantasy, fairy tale, rather than a horror or monster film in general. The images allow us to see the true beauty of the creature. The director's attention and the work and care of the whole creative team bring each detail, colour, and effect together, to create an entertaining and inspiring visual experience.

\section{CONCLUSIONS}

Summarising the main topics addressed here, it could be said that:

- Guillermo del Toro's distinctive style and voice as an auteur provides viewers with detailed, well crafted, and visually appealing stories where particular attention is paid to colour palettes, visual effects, and loveable characters, often in the realm of fantasy, and The Shape of Water is an example of this.

- Monsters in cinema, while still often bearing the shape of something we consider as "other", are no longer only villains but take on a more significant role of carrying the message of reflection, acceptance, and embracing otherness.

- References to similar stories of human and sea creature relationships, and the myths surrounding such creatures reveal the idea of conflict both in the relationships and the creatures themselves with their good and bad sides present. The Amphibian Man follows these inspirations and is a similarly complex character.

A closer look at The Shape of Water reveals that this work of art is not just a "woman falls in love with an amphibian creature" film. Guillermo del Toro brings many ideas together to create an intelligent, beautiful, 
and loveable, yet mystical and powerful monster - a representation of many myths about similar creatures and stories about them. Putting him at the centre, making him a love interest, a protagonist in a way, is a step up from the Gill-man of the Black Lagoon, and fits in with the recent trend of positive monster representation, seeing them as more than villains, threats and in need of slaying. Here the real monster turns out to be someone else entirely. The Amphibian Man helps to address the themes of acceptance, embracing otherness, and further defines del Toro's love of monsters. The director's hand can also be felt in many different elements that connect the film - sound, camera work, colours, and production design - as they all complement each other and make sense in the fairy tale world that del Toro aims and achieves to construct.

\section{REFERENCES}

Adji, Alberta Natasia. 2019. "Falling for the Amphibian Man: Fantasy, Otherness, and Auteurism in del Toro's The Shape of Water". IAFOR Journal of Media, Communication E Film 6 (1): 51-64. doi: 10.22492/ijmcf.6.1.03.

Bane, Theresa. 2016. Encyclopedia of Beasts and Monsters in Myth, Legend and Folklore. Jefferson (NC): McFarland \& Company.

Bassil-Morozow, Helena. 2010. Tim Burton: The Monster and the Crowd: A PostJungian Perspective. London: Routledge.

Bernardi, Verena, and Frank Jacob, eds. 2019. All Around Monstrous: Monster Media in Their Historical Contexts. Wilmington (DE): Vernon Press.

Bloom, Abigail Burnham. 2010. The Literary Monster on Film: Five Nineteenth Century British Novels and Their Cinematic Adaptations. Jefferson (NC): McFarland \& Company.

Chimera Lighting. N.D. "Dan Lausten-ASC, Shape of Water". https://chimeralighting. com/shape-of-water/

Creature from the Black Lagoon. 1954. Directed by Jack Arnold. Universal International Pictures (UI).

Davies, Ann, Deborah Shaw, and Dolores Tierney, eds. 2014. Introduction to The Transnational Fantasies of Guillermo del Toro, 1-8. New York: Palgrave Macmillan.

del Toro, Guillermo, and Marc Scott Zicree. 2013. Cabinet of Curiosities: My Notebooks, Collections, and Other Obsessions. New York: Harper Collins.

del Toro, Guillermo, and Vanessa Taylor. 2016. The Shape of Water. Screenplay: For Your Consideration. https://screenplayed.com/scriptlibrary/the-shapeof-water-2017.

Grant, Barry Keith. 2018. Monster Cinema. New Brunswick: Rutgers University Press. 
Grobar, Matt. 2017. “'The Shape of Water' Composer Alexandre Desplat on the Sounds of Love and Water". Last modified December 30. https:// deadline.com/2017/12/the-shape-of-water-alexandre-desplat-oscarsinterview-1202220056/

Grobar, Matt. 2018. “'The Shape of Water' Production Designer on Crafting Satisfying Visual Experience for Ultimate Visual Storyteller”. Last modified April 11. https://deadline.com/2018/01/the-shape-of-water-paul-dausterberry-production-designer-interview-news-1202230180/

Internet Movie Database. N.D. “The Shape of Water (2017)”. https://www.imdb. com/title/tt5580390/

James, Daron. 2017. "Colors Play a Key Role in Production Design of Guillermo del Toro's 'Shape of Water'”. Last modified December 8. https:// variety.com/2017/artisans/production/guillermo-del-toro-shape-ofwater-1202633301/

Jenkins, David. 2018. "Guillermo del Toro: 'Perversity is Always in the Eye of the Beholder'”. Last modified February 14. https://lwlies.com/interviews/ guillermo-del-toro-the-shape-of-water/

Martinelli, Dario. 2014. Lights, Camera, Bark. Kaunas: Technologija.

Martinelli, Dario. 2020. What You See Is What You Hear: Creativity and Comunication in Audiovisual Texts. Cham: Springer.

Misek, Richard. 2010. Chromatic Cinema: A History of Screen Color. Malden (MA): Wiley-Blackwell.

Punday, Daniel. 2002. "Narrative Performance in the Contemporary Monster Story". The Modern Language Review 97 (4): 803-820. http://www.jstor. org/stable/3738613

Ruiz, Elvin E., and Carmel Vip C. Derasin. 2019. "Dili Ingun Natu as Wardens of Nature". International Journal of Humanities and Social Science Research 5 (3): 58-62.

Sallisbury, Joyce E. (1994) 2011. The Beast Within: Animals in the Middle Ages. New York: Routledge.

Staples, Donald E. 1966. “The Auteur Theory Reexamined”. Cinema Journal 6: 1-7. doi: $10.2307 / 1225411$.

Stymeist, David. 2009. "Myth and the Monster in Cinema". Antbropologica 51 (2): 395-406. https://www.jstor.org/stable/25605494

The Shape of Water. 2017. Directed by Guillermo del Toro. Double Dare You (DDY), Fox Searchlight Pictures.

Wade, Joseph. 2018. “The Shape of Water (2017/18) Review”. Last modified January 12. https://www.thefilmagazine.com/shape-of-water-review/

Walden, Jennifer. 2018. "Behind the Shape of Water's Retro-Futuristic Fairytale Sound". Last modified February 20. https://www.asoundeffect.com/theshape-of-water-sound/

Ward, Glenn. 2014. “'There Is No Such Thing': del Toro's Metafictional Monster Rally”. In The Transnational Fantasies of Guillermo del Toro, edited by Ann Davies, Deborah Shaw, and Dolores Tierney. New York: Palgrave Macmillan.

Relations - 9.1-2 - November 2021

https://www.ledonline.it/Relations/ - Online ISSN 2280-9643 - Print ISSN 2283-3196 
Weinstock, Jeffrey Andrew. 2012. "Invisible Monsters: Vision, Horror, and Contemporary Culture". In The Ashgate Research Companion to Monsters and the Monstrous, edited by Asa S. Mittman and Peter Dendle, 275-289. Farnham (Surrey): Ashgate.

Whitley-Berry, Victoria. 2017. “Guillermo del Toro Says 'Shape of Water' is an Antidote for Today's Cynicism”. Last modified December 1. https://www. npr.org/2017/12/01/567265511/guillermo-del-toro-says-shape-of-water-isan-antidote-for-today-s-cynicism? $\mathrm{t}=1612730428623$

Wood, Juliette. (2014) 2016. “Mermaid/Merman”. In Ashgate Encyclopedia of Literary and Cinematic Monsters, edited by Jeffrey Andrew Weinstock. Farnham (Surrey): Ashgate.

Zahed, Ramen. 2018. "Strong Color Palette Brings a Long-Held Vision of Shape of Water to Life". Last modified January 25. https://www.latimes. com/entertainment/envelope/la-en-mn-crafts-shape-water-design20180125-story.html 